\title{
Recognizing the possibility of bioterrorism in the face of emerging and reemerging zoonotic pathogens in Bosnia and Herzegovina during the war (1992-1995)
}

\author{
Mirsada Hukić ${ }^{1,2 *}$, Sead Ahmetagić ${ }^{3}$, Nijaz Tihić ${ }^{4}$, Nermina Mehinovic ${ }^{5}$, Denijal Tulumović ${ }^{6}$, Mirza Ponjavic $^{5}$ and Paul Heyman $^{5}$ \\ ${ }^{1}$ Department of Medical Science, Academy of Sciences and Arts of Bosnia and Herzegovina, Sarajevo, Bosnia and Herzegovina \\ ${ }^{2}$ Institute for biomedical diagnostic and research Nalaz, Sarajevo Bosnia and Herzegovina \\ ${ }^{3}$ Clinic for Infectious Diseases, University Clinical Centre Tuzla, Tuzla, Bosnia and Herzegovina \\ ${ }^{4}$ Institute of Microbiology, University Clinical Centre Tuzla, Tuzla, Bosnia and Herzegovina \\ ${ }^{5}$ Institute for Biomedical Diagnostic and Research Nalaz, Sarajevo Bosnia and Herzegovina \\ ${ }^{6}$ Clinic of Internal Medicine University Clinical Centre Tuzla, Tuzla, Bosnia and Herzegovina
}

\begin{abstract}
Tularemia is a vector-borne zoonosis with a complex epidemiology caused by Francisella tularensis. F. tularensis is a non-motile, obligatory aerobic, facultative intracellular Gram-negative coccobacillus. The bacterium has a broad host range, i.e. mammals, birds and invertebrates. Two types (A, B) and four subspecies ( $F$. tularensis subsp. tularensis (type A), F. tularensis subsp. holarctica (type B), F. tularensis subsp. mediasiatica and $F$. tularensis subsp. novicida.) are known today. Types $\mathrm{A}$ and $\mathrm{B}$ are of importance as they cause disease in humans and animals. Type A is present almost exclusively in North America and type B is found all over the Northern hemisphere.
\end{abstract}

F. tularensis is considered to be a class A biological warfare agent, it is notoriously difficult to recognize infections in non-endemic regions and was produced as a weaponized agent by several countries in the 1960ties and 70ties.

Humans can acquire tularemia by inhaling dust or aerosols contaminated with $F$. tularensis bacteria, this type of exposure can result in pneumonic tularemia, one of the most severe forms of the disease. especially farming involving machines that disperse remains of infected animals or carcasses. Rarely, water can become tularemia contaminated through contact with infected animals. Humans who drink contaminated and untreated water may contract oropharyngeal tularemia.

The tularemia outbreak in B\&H in 1995 showed an unusual number of oropharyngeal cases. As all aspects of this particular tularemia epidemic were not thoroughly investigated and the possible intentional use of agents of biological warfare remained a possibility, we reviewed all available data in order to assess whether the outbreak was natural.

\section{Introduction}

Tularemia is a vector-borne zoonosis with a complex epidemiology caused by Francisella tularensis.

F. tularensis is a non-motile, obligatory aerobic, facultative intracellular Gram-negative coccobacillus. The bacterium has a broad host range, i.e. mammals, birds and invertebrates. Four subspecies are known today; F. tularensis subsp. tularensis (type A), F. tularensis subsp. holarctica (type B), F. tularensis subsp. mediasiatica and F. tularensis subsp. novicida. Types A and B are of importance as they cause disease in humans and animals. Type A is present almost exclusively in North America and type B is found all over the Northern hemisphere [1].

Infections due to tick and deer fly bites usually take the form of ulceroglandular or glandular tularemia. F. tularensis bacteria can also be transmitted to humans via the skin when handling infected animal tissue. This can occur when hunting or skinning infected rodents like rabbits, muskrats and other rodents. Many animals have also been known to become infected and clinically ill from tularemia. Domestic cats are very susceptible and can transmit the bacteria to their owners. Therefore, care should always be taken when handling sick or dead animals. Infection due to handling animals can result in glandular, ulceroglandular and oculoglandular tularemia. Eating of under-cooked meat of infected animal's tularemia can also result in oropharyngeal tularemia [2]. Humans can acquire tularemia by inhaling dust or aerosols contaminated with $F$. tularensis bacteria, this type of exposure can result in pneumonic tularemia, one of the most severe forms of the disease. especially farming involving machines that disperse remains of infected animals or carcasses. Rarely, water can become tularemia contaminated through contact with infected animals. Humans who drink contaminated and untreated water may contract oropharyngeal tularemia [3]. Transmission from person to person has so far not been reported.

Inhalational tularemia following intentional release of a virulent strain of $F$. tularensis would have the greatest adverse human

Correspondence to: Mirsada Hukić, Institute for Biomedical Diagnostic and Research Nalaz, Sarajevo Bosnia and Herzegovina, Tel: +387-33-651 371; E-mail:mirsadahukic@yahoo.com

Received: May 23, 2017; Accepted: June 20, 2017; Published: June 22, 2017 
consequence because of its very high infectivity if delivered as an aerosol. It has been estimated that an aerosol dispersal of $50 \mathrm{~kg}$ of virulent $F$. tularensis over a metropolitan area with 5 million inhabitants would result in 250000 incapacitating casualties, including 19,000 deaths. Outbreaks of pneumonic tularemia, particularly in low incidence areas, should prompt consideration of bioterrorism.

F. tularensis has long been considered a potential biological weapon. It was one of the agents studied the Japanese germ warfare research units in Manchuria, China between 1932 and 1945; it was also considered for military purposes in the West [4]. An outbreak of tularemia reported in Soviet and German soldiers during the second world war may have been the result of intentional release [5]. F. tularensis has been studied, weaponized and stockpiled by several countries, including Japan, the USSR and the US [4].

\section{Pathogenesis}

Francisella tularensis can infect humans through the skin, mucous membranes, gastrointestinal tract, and lungs. The major target organs are the lymph nodes, lungs and pleura, spleen, liver, and kidney. Bacteremia is common in the early phase of infection. The initial tissue reaction to infection is a focal, suppurative necrosis. Suppurative lesions become granulomatous, typical of other granulomatous conditions, i.e. tuberculosis or sarcoidosis. Humans with inhalational exposure also develop early in the course of illness hemorrhagic signs and inflammation of the airways which usually evolves to bronchopneumonia.

\section{Clinical manifestations}

The primary clinical forms of tularemia vary in severity and presentation according to virulence of the infecting organism, the dose, and way of administration. Primary disease presentations can be glandular, ulceroglandular, oculoglandular, oropharyngeal, pneumonic, typhoidal, and septic forms. The onset of tularemia is usually abrupt, with fever $\left(38^{\circ} \mathrm{C}-40^{\circ} \mathrm{C}\right)$, headache, chills and rigors, generalized body aches (lower back pain) and sore throat. A dry or slightly productive cough frequently occurs with or without signs of pneumonia. Nausea, vomiting, and diarrhea sometimes occur. Sweats, fever and chills, malaise, progressive weakness and weight loss characterize the continuing illness. In untreated tularemia, symptoms often persist for several weeks or months. Any form of tularemia may be complicated by hematogenous spread, resulting in secondary pleura-pneumonia, sepsis, and meningitis. Prior to the administration of antibiotics, the overall mortality with the more severe type A strains is of $5 \%$ to $15 \%$, and in the case of untreated pneumonic and severe systemic forms fatality rates as high as $30 \%$ to $60 \%$ were reported. Type $\mathrm{B}$ infections are in contrast rarely fatal.

Ulceroglandular tularemia, after handling a contaminated carcass or due to an infective arthropod bite, a local cutaneous papule appears at the inoculation site together with the onset of generalized symptoms, becomes pustular, and ulcerates within a few days. The ulcer is tender may show an eschar. Antibiotic treatment does not prevent the affected nodes from becoming fluctuant and rupture.

Oculoglandular tularemia, which follows direct contamination of the eye, ulceration occurs on the conjunctiva, accompanied by pronounced chemosis, vasculitis, and regional lymphadenitis.

Glandular tularemia is characterized by lymphadenopathy without an ulcer.
Oropharyngeal tularemia is acquired by drinking contaminated water, ingesting contaminated food, or by inhaling contaminated droplets or aerosols. Affected persons may develop stomatitis but more commonly develop exudative pharyngitis or tonsillitis, sometimes with ulceration.

Tularemia pneumonia is the direct result of inhaling contaminated aerosols. Inhalational exposures commonly result in an initial clinical picture of systemic illness without prominent signs of respiratory disease. The earliest pulmonary radiographic findings of inhalational tularemia may be peribronchial infiltrates, typically advancing to bronchopneumonia in one or more lobes. Pulmonary infection can sometimes rapidly progress to severe pneumonia, respiratory failure, and death. Lung abscesses occur infrequently.

Typhoidal tularemia is used to describe systemic illness when the site of inoculation or the localization of infection is unclear.

Tularemia sepsis is severe and potentially fatal. As in the case of typhoidal tularemia, fever, abdominal pain, diarrhea, and vomiting may be prominent early in the course of illness. The patient typically appears toxic and may develop confusion and coma. Unless treated promptly, septic shock and other complications of systemic inflammatory response syndrome may develop with hemorrhagic signs, acute respiratory distress syndrome and organ failure [4].

\section{The war in Bosnia and Herzegovina (B\&H) (1992-1995)}

As in all conflicts, the inhabitants of Bosnia and Herzegovina were under extreme pressure during the war that took place 1992-1995. Due to the nature of the conflict that sometimes involved hostilities amongst neighbors, there was minimal respect for human rights and civilians, children and old people as well as soldiers suffered the consequences. In particular the weakest individuals, namely women and children suffered the most. Horrific ethnic cleansing campaigns between 1992 and the end of 1995 killed thousands and violently displaced more than two million people in much of $\mathrm{B} \& \mathrm{H}$. International intervention into the Bosnian conflict led finally to a peace agreement in late 1995 (the Dayton Accords). The Dayton agreement finally ended the war in B\&H.

In 1995, the conflict between multiple factions was aggravated by extreme meteorological conditions in $\mathrm{B} \& \mathrm{H}$. During that year, $\mathrm{B} \& \mathrm{H}$ also experienced the genocide against the Muslim population in Srebrenica in the eastern part of the country, during this mass murder 8,373 killed men were killed.

Another consequence of the conflict were outbreaks of many emerging and reemerging diseases, with a severe clinical presentation and high mortality. The largest and most prominent outbreaks were a Hemorrhagic fever with renal syndrome (HFRS) epidemic with thousands of reported cases and a tularemia outbreak with hundreds of reported cases.

The outbreak of tularemia occurred in various parts of $\mathrm{B} \& \mathrm{H}$, but the epidemic in north-east Bosnia was unusual and different from those in other parts of the country. It also coincided with the genocide in Srebrenica and the HFRS epidemic. All aspects of the tularemia epidemic were not investigated thoroughly and the possible intentional use of agents of biological warfare remained unexplored.

\section{Epidemiology}

Tularemia is widely distributed over the Eurasian continent. The highest prevalence are found in the Northern part, i.e., the former Soviet Union and Scandinavia (ulceroglandular tularemia) [6]. Great 
Hukić M (2017) Recognizing the possibility of bioterrorism in the face of emerging and reemerging zoonotic pathogens in Bosnia and Herzegovina during the war (1992-1995)

Britain and Ireland are disease free. In Germany, Italy and France only sporadic cases are reported each year [7]. In Turkey, 205 cases were noted in the late 1990s associated with use of drinking water from a natural aqueduct [8]. In Spain, tularemia in humans was first reported in 1996, when 585 cases occurred associated with hare hunting [9]. In parts of Moravia, Slovakia and Austria, tularemia occurs endemically, the annual incidence varying from 1 to 5 cases per 100,000 inhabitants [10]. During World War II, Eastern Europe suffered epidemics with 10,000 to 100,000 cases each year, particularly outbreaks of waterborne tularemia.

In Kosovo in 1999-2000, 327 cases of tularemia were reported. The principal populations affected by the tularemia outbreak were ethnic Albanians living in rural area. These populations fled to neighboring areas during NATO bombing and Serbian reprisals in spring 1999. When the refugees returned they found a vastly disordered environment with ransacked and partly burned homes, abandoned and disturbed food storages and unharvested crops left in the fields.

\section{Aim of the study}

Two decades after the facts, we conducted a retrospective analysis of the 1995 tularemia outbreak with the aim to discern whether its occurrence was due to a natural outbreak or due to intentional use of biological warfare agents.

\section{Materials and methods}

We researched epidemiological, clinical and microbiological aspects of the outbreak of tularemia. The analysis includes:

- Reports of the WHO team,

- Meeting minutes of the Institute of Public Health of Tuzla Canton

- Epidemiological reports of the Institute of Public Health of B\&H,

- Reports of field inspections from the special team nominated from the Public Health and Clinical Centre University of Tuzla,
- Interviews of patients received in hospital have done by doctors and interviews of member of their family have done by epidemiologists,

- Medical records,

- Microbiological and immunological findings

- Geographical maps of the different areas affected by the epidemic, including (plan water supply, arrangement of military forces in the field)

- The politico-military, social and ecological situation and on intelligence information gathered

- Comparison of clinical and epidemiological characteristics of two concurrent epidemics in $\mathrm{B} \& \mathrm{H}$

\section{Methodology}

\section{Study locations}

We studied the outbreak of tularemia in two locations, $120 \mathrm{~km}$ apart: the Municipality of Tuzla (north-east Bosnia) and the rural area between two Cantons, Zenica-Doboj Canton and Central Bosnia Canton (around towns Bugojno, Travnik, Novi Travnik, and Tešanj) (155000 and 152547 inhabitants, respectively, in 1995) (Figure 1).

During the time of the outbreak, the Bosnian Army and Serbian forces were battling intensively, and the front line was only about two kilometers from the Tuzla region. Travnik, on the other hand, did not face this upheaval.

The Public Health and Clinical Centre University of Tuzla appointed a team that visited the area of Tuzla that was affected by the epidemic, interviewed patients' relatives, and inspected their homes, gardens and water supply systems.

The Travnik region was investigated based on the reports from WHO team and the Institute of Public Health.

Investigations pertaining to the outbreak of tularemia in the regions that were under control of the Serbian forces remains impossible as no data could be obtained, even two decades later.

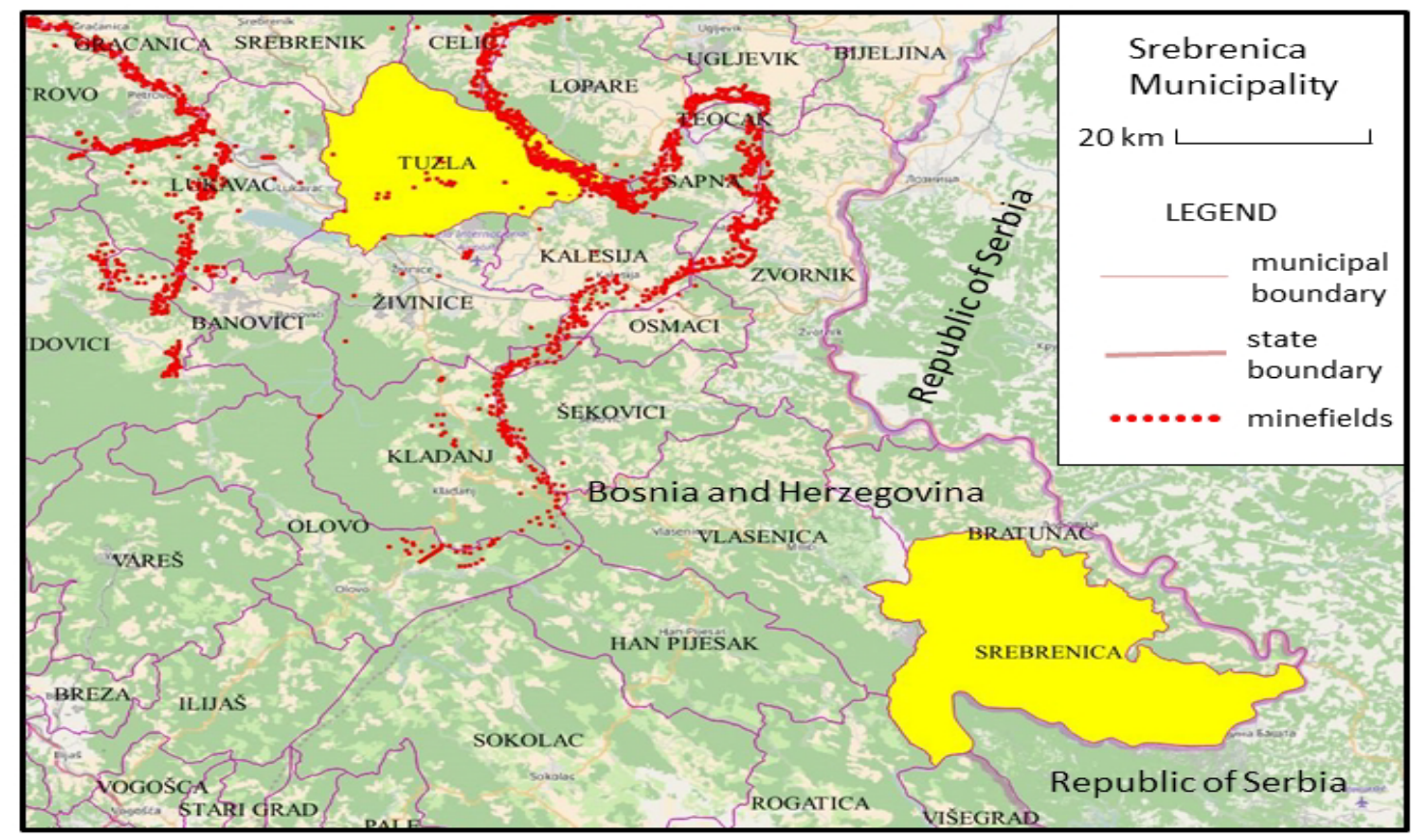

Figure 1. Geographical position of the battlefields in the east of Bosnia and by epidemic attack area, Tuzla and besieged Srebrenica as well as position of the mine field areas. 


\section{Identification of tularemia}

Until 1995, tularemia was an unknown disease in Bosnia and Herzegovina, except for a few sporadic cases that occurred in the north-west part of the country. Due to extraordinary difficulties of the war, confirming diagnosis after disease onset took two months. This lag leads to both no reporting and to other limitations in the investigation.

\section{Clinical and laboratory diagnostics of tularemia}

Clinical diagnosis was confirmed by ELISA IgG and IgM tests at the Institute for Microbiology Clinical Centre University of Tuzla and at the Swedish Defense Research Agency, Umeå, Sweden, Umeå University Hospital Sweden, and by indirect hemoagglutination method at Croatian Veterinary Institute, Zagreb.

For diagnosis conformation, 30 blood samples from Tuzla have been sending through Norbat to Sweden and seven blood samples from Zenica-Travnik region were sent to Zagreb by WHO.

In Sweden, ELISA IgM and IgG tests were performed, in which relative titers (optical density at $405 \mathrm{~nm}$ ) of serum dilution of $1 / 500$ were determined. The antigen used is partially purified from vaccine strains of F. tularensis. This antigen has previously been used extensively as antigen in ELISA determinations. The conjugates specific for human IgG or IgM antibodies were supplied by Dakopatts (Santa Clara, CA, USA). The Croatian Veterinary Institute in Zagreb performed serology tests using the hemaglutination method.

\section{Patient interviews and geographic mapping}

To obtain geographic data on likely way and places of disease transmission in Tuzla, patients admitted to the hospital with tularemia in 1995 were interviewed upon admission. They we asked to give information about potential contacts with rabbits, rodents and about their activities in the forest and field. Also, sources of water supply were investigated and possible sites where patients believed they had been infected were marked. We visualized and analyzed geographic distribution of infected persons as well as water supply systems and front lines with mine fields.

\section{Assessment of sources of infection}

The unusual outbreak of tularemia in the area of northeast $\mathrm{B} \& \mathrm{H}$ is assessed in qualitative terms using non-conclusive criteria, which may indicate indirectly that biological warfare agents have been used (Table 1).

A conclusive criterion (identification of the agent as a biological warfare agent and proof of the release of the agent as a biological weapon) was not available [11].

\section{Results}

\section{The spatial structure of epidemic emergence. Geographical aspects of tularemia in central and north-eastern Bosnia, May} 1995.

A total of 272 cases were reported during the epidemic of tularemia in B\&H: 171 occurred in the area under the control of the Army of $\mathrm{B} \& \mathrm{H}$ and 101 in the area under control Serbian forces. In the area under Army control outbreak two epidemics: Study Locations

We studied the outbreak of tularemia in two locations, $120 \mathrm{~km}$ apart: the Municipality of Tuzla (north-east Bosnia) and the rural area between two Cantons, Zenica-Doboj Canton and Central Bosnia Canton (around towns Bugojno, Travnik, Novi Travnik, and Tešanj) (155000 and 152547 inhabitants, respectively, in 1995) (Figure 2).
Table 1. Clinical forms of tularemia in two affected areas under control of Army of Bosnia and Herzegovina during the outbreak in 1995.

\begin{tabular}{|c|c|c|}
\hline \multirow{2}{*}{ Clinical forms of tularemia } & \multicolumn{2}{|c|}{ Number of tularemia cases } \\
\hline & The Municipality of Tuzla & The area Travnik/Zenica \\
\hline Oropharyngeal & 147 & 10 \\
\hline & & 7 \\
\hline Oculoglandular & 2 & 4 \\
\hline Ulceroglandular & & 1 \\
\hline Pneumonic & & \\
\hline Typhoidal & & \\
\hline Septic forms & & 22 \\
\hline TOTAL: & 149 & \\
\hline
\end{tabular}

\section{Dynamic and spread of the epidemic, reported cases, hospitalized patients}

Location 1. Zenica-Doboj Canton and Central Bosnia Canton

A total of 22 cases of tularemia were reported from the Zenica-Travnik region during the months of April and May of 1995. This group consisted of 20 men, aged between 21 and 33, and two women, age 40 .

The first three reported cases of tularemia were soldiers from Novi Travnik who were diagnosed in the Zenica regional hospital in late April. These three men (two brothers and a friend) had skinned rabbits 10-21 days before their symptoms began in February and March. A field investigation in late April revealed family members who were otherwise healthy.

One case that presented as pulmonary - systemic tularemia was treated for tuberculosis, the anamnesis revealed a history of wearing rabbit skin around the neck (for warmth) two days before onset of symptoms.

During May of 1995, another 18 cases were found in the Zenica region, namely 13 from one municipality, and five in various other locations. None of the infected individuals reported having had contact with rabbits or ticks. The clinical presentation of the findings comprised four forms of ulceroglandular tularemia, one pulmonary, seven glandular and ten pharyngeal-glandular types. The type of clinical picture is depicted in Table 2.

Location 2. The municipality of the city of Tuzla

Total number of 149 (110 men and 39 women) clinical cases tularemia were reported to the Public Health Institute in Tuzla. The municipality Gornja Tuzla, with 70 cases reported on 5000 citizens, or $1.4 \%$, was recognized as the infection focus. In the University Clinical Centre Tuzla 54 patients were admitted and 95 individuals were cared for in health centers. The youngest patient was six and the oldest 77 years old, with the median age of 30.5 years $( \pm 13.57$ ). The group of patients from focal zone was consisted of $57 \%$ soldiers (40/70) and $43 \%$ civilians (30/70). Among the patients were children and one pregnant woman. Occupation of 70 patients from the zone of explosion of infection is shown on the Figure 3.

The first cases were admitted in the Clinic for Infectious Diseases, University Clinical Centre Tuzla on 14 April 1995 and retrospectively diagnosed as suspected cases of tularemia (Figure 4).

Surprising, in the all cases (except one) clinical presentation of disease was tonsillitis/ pharyngitis type, an angina-like syndrome, with regional lymph node swelling and indication of infection through ingestion (Table 2). Oculoglandular cases could be put in connections with contaminated water. 
Hukić M (2017) Recognizing the possibility of bioterrorism in the face of emerging and reemerging zoonotic pathogens in Bosnia and Herzegovina during the war $(1992-1995)$

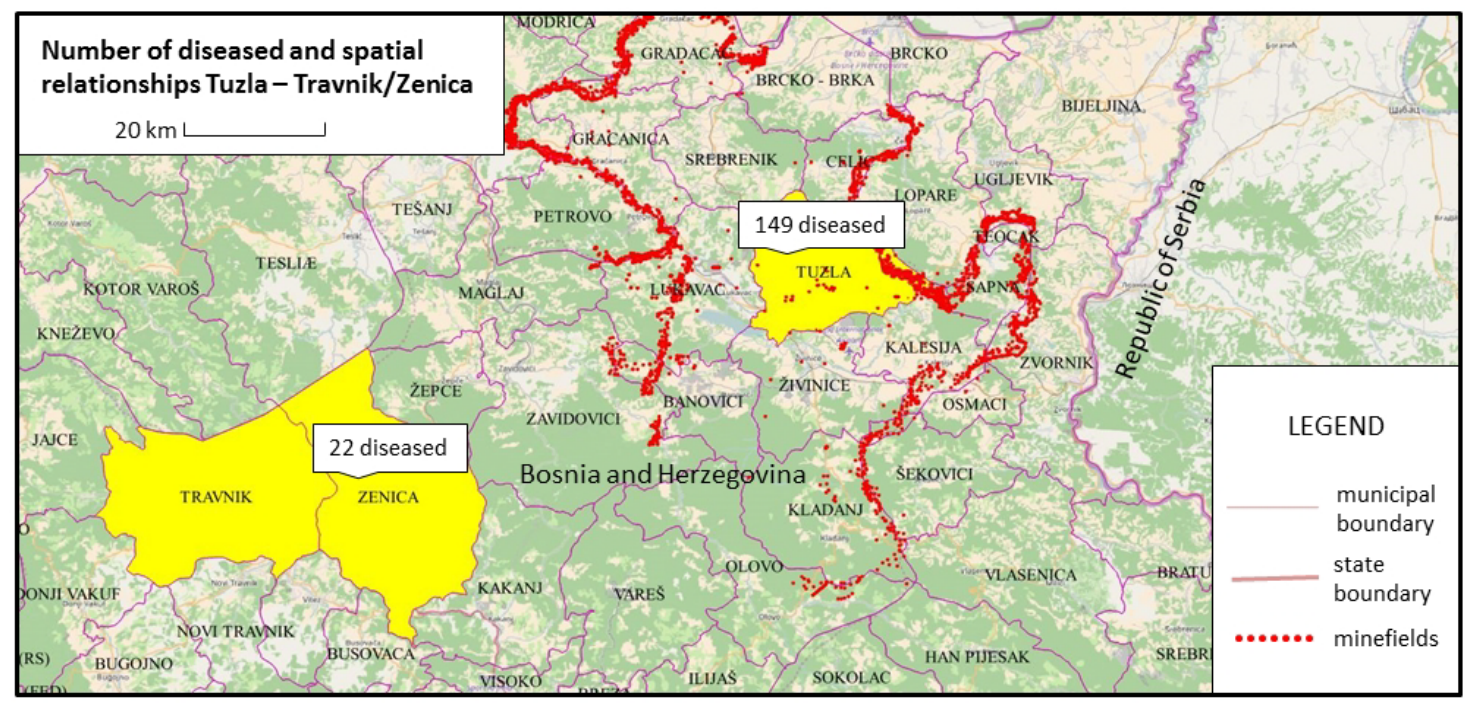

Figure 2. Geographical position of two affected areas the Municipality of Tuzla (north-east Bosnia) and the rural area between two Cantons, Zenica-Doboj Canton and Central Bosnia Canton (around the towns Travnik and Zenica), and cumulative number of tularemia cases per the location in 1995.

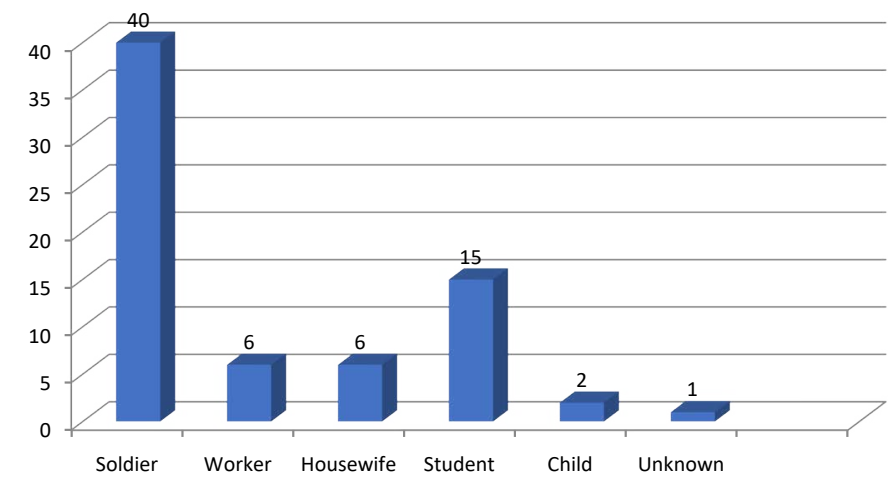

Figure 3. Occupation of the tularemia patients from the zone of explosion of infection Total number 70

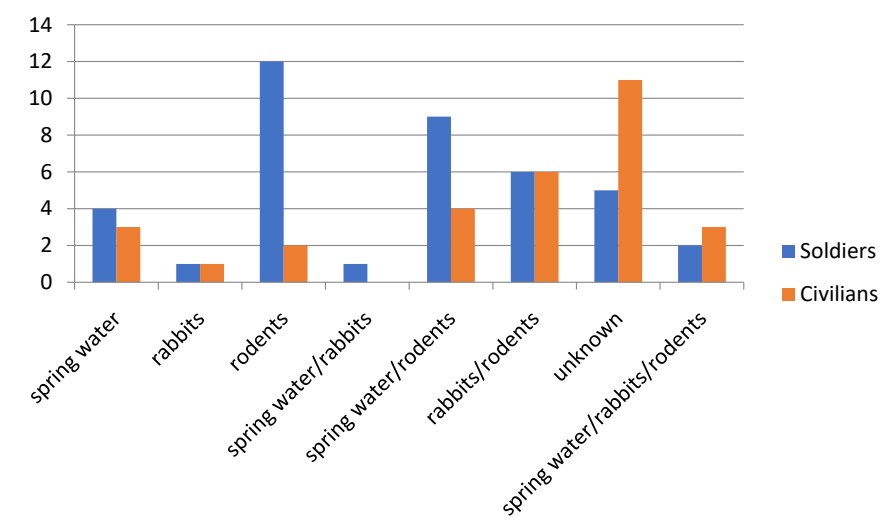

Figure 4. Number of tularemia cases per month in 1995 in B\&H.

Analysis of interview transcripts with 70 patients highlighted that all patients had been in contact with water from the local water distribution system. Furthermore, some of them used spring water and had been in contact with rabbits and rodents (Figure 5).

Reports of field inspections that were performed by the special team appointed by the Public Health and Clinical Centre University of Tuzla showed that water supplying system in Gornja Tuzla was
Table 2. Assessing the likelihood of the use of a biological warfare agent based on nonconclusive criteria.

\begin{tabular}{|c|c|c|c|c|}
\hline No. & Criterion & $\begin{array}{c}\text { Assessment } \\
\text { (possible } \\
\text { points) }\end{array}$ & $\begin{array}{l}\text { Weight-in } \\
\text { factor }\end{array}$ & Points \\
\hline 1 & Existence of a biological risk & $0-3$ & 2 & 6 \\
\hline 2 & Existence of a biological threat & $0-3$ & 3 & 9 \\
\hline 3 & Special aspects of the biological agent & $0-3$ & 3 & 9 \\
\hline 4 & $\begin{array}{l}\text { Peculiarities of the geographic distribution } \\
\text { of the biological agent }\end{array}$ & $0-3$ & 1 & 3 \\
\hline 5 & $\begin{array}{l}\text { High concentration of the biological agent } \\
\text { in the environment }\end{array}$ & $0-3$ & 2 & 6 \\
\hline 6 & $\begin{array}{l}\text { Peculiarities of the transmission mode of } \\
\text { the biological agent }\end{array}$ & $0-3$ & 1 & 3 \\
\hline 7 & $\begin{array}{l}\text { Peculiarities of the intensity and dynamics } \\
\text { of the epidemic }\end{array}$ & $0-3$ & 2 & 6 \\
\hline 8 & Peculiarities of the time of the epidemic & $0-3$ & 1 & 3 \\
\hline 9 & Unusually rapid spread of the epidemic & $0-3$ & 1 & 3 \\
\hline 10 & $\begin{array}{l}\text { Limitation of the epidemic to a specific } \\
\text { population }\end{array}$ & $0-3$ & 1 & 3 \\
\hline 11 & Peculiarities of the clinical manifestation & $0-3$ & 1 & 3 \\
\hline \multicolumn{4}{|c|}{ Total } & 54 \\
\hline
\end{tabular}

damaged and made accessible to unauthorized persons. The two water reservoirs were only 1000 meters away from the front lines (Figure 6).

\section{Rumors and hypothesis}

Evaluation:

Specificities among populations that were infected. Soldiers only (Novi Travnik) vs. civilians and soldiers (Tuzla).

1. Existence of a biological risk

2. Existence of a biological threat

3. Special aspects of the biological agent

4. Peculiarities of the geographic distribution of the biological agent

5. High concentration of the biological agent in the environment

6. Peculiarities of the transmission mode of the biological agent

7. Peculiarities of the intensity and dynamics of the epidemic 


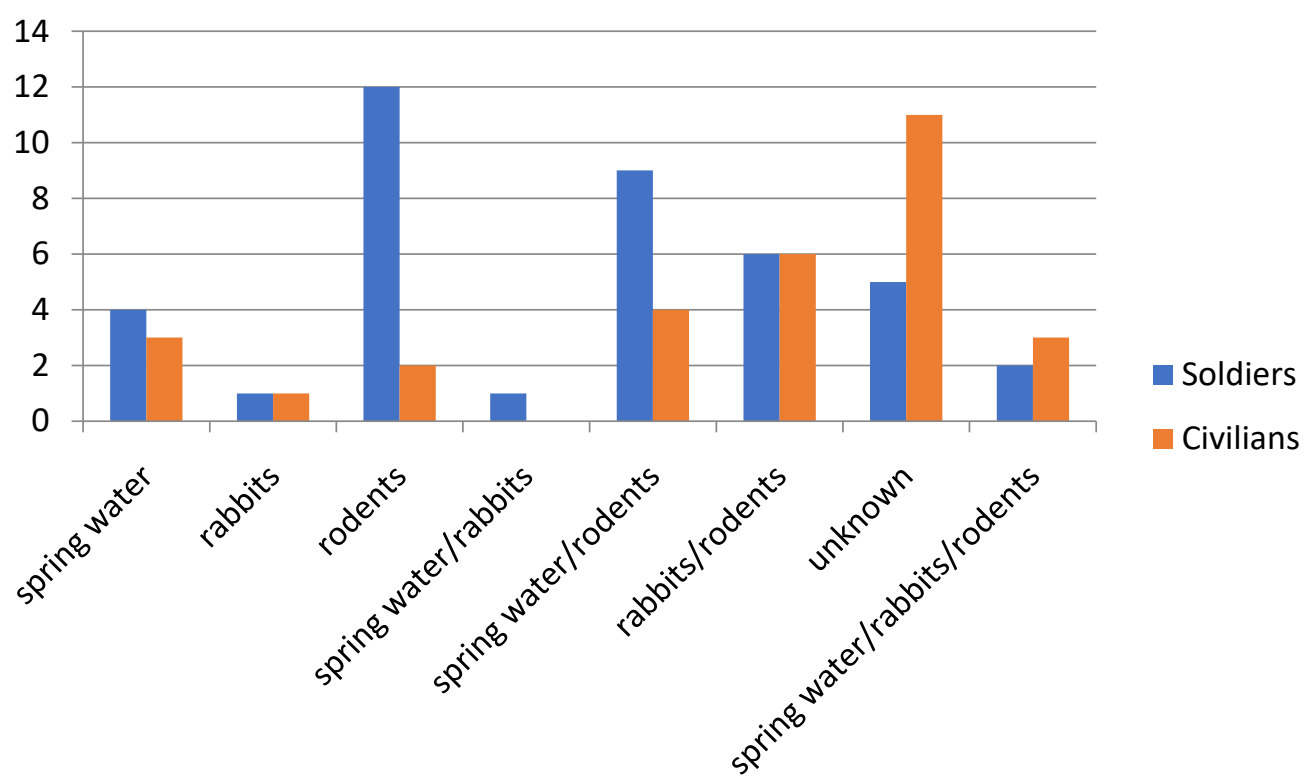

Figure 5. Infection Risk Factors for tularemia selected by 70 patients that were infected in the zone of explosion of infection, Gornja Tuzla in 1995 .

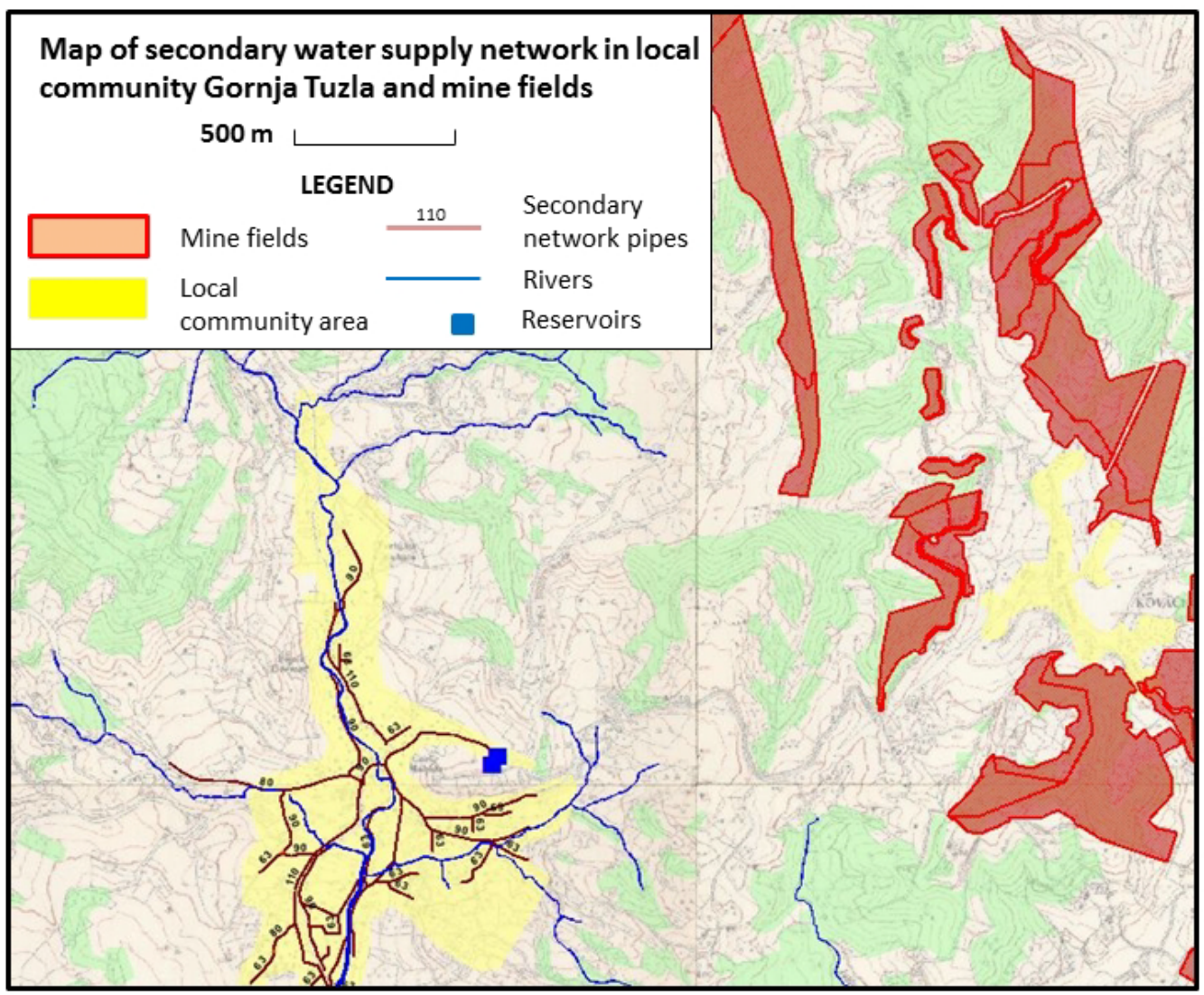

Figure 6. The community area affected by the epidemic, with the plan of water supply system, arrangement of military forces in the field and mines fields

8. Peculiarities of the time of the epidemic

9. Unusually rapid spread of the epidemic

10. Limitation of the epidemic to a specific population

11. Peculiarities of the clinical manifestation

\section{Conclusion}

Ulceroglandular tularemia ( $75 \%$ to $85 \%)$ is the most common form reported in patients with tularemia and occurs in $75 \%$ to $85 \%$ of the diagnosed cases, oropharyngeal tularemia, acquired by drinking contaminated water or ingesting contaminated food, on 
the other hand is more rare and is diagnosed in about $25 \%$ of the cases [12].

The tularemia outbreak in 1995 in N-E Bosnia was therefore exceptional as all the Tuzla cases were diagnosed as oropharyngeal tularemia. This finding combined with the assessment of the likelihood of the use of a biological warfare agent (Table 2) $[4,11]$ opens the debate regarding the nature -natural of induced- of this particular outbreak. It is, on the other hand clear, that the sub-standard housing and living conditions, lack of food and clean water in war time contribute to the emergence of a variety of infectious diseases.

To our knowledge, no conflict in the past 2000 years occurred without epidemics [13]. There is also the fact that in almost all wars the number of fatalities due to diseases exceed the number of deaths due to combat activities [14]. Finally, in modern warfare, i.e. the 20th and 21 st century conflicts, the number of civilian fatalities usually exceeds the combat casualties due to the variety and nature of the arms but also due to deteriorated sanitary and public health conditions [15]. The Convention on the Prohibition of the Development, Production and Stockpiling of Bacteriological (Biological) and Toxin Weapons and on their Destruction, commonly known as the Biological Weapons Convention (BWC) or Biological and Toxin Weapons Convention (BTWC), entered into force in 1975 and should prevent the use of chemical and/or biological agents. Unfortunately, there are indications that this is still not the case.

\section{Conflict of interest}

The authors declare that they have no conflict of interest.

\section{References}

1. Hestvik G, Warns-Petit E, Smith LA, Fox NJ, Uhlhorn H, et al. (2015) The status of tularemia in Europe in a one-health context: a review. Epidemiol Infect 143: 2137-2160. [Crossref]
2. Keim P, Johansson A, Wagner DM (2007) Molecular epidemiology, evolution, and ecology of Francisella. Ann N Y Acad Sci 1105: 30-66.[Crossref]

3. Maurin M, Gyuranecz M (2016) Tularaemia: clinical aspects in Europe. Lancet Infect Dis 16: 113-124.[Crossref]

4. Dennis DT, Inglesby TV, Henderson DA, Bartlett JG, Ascher MS, et al. (2001) Tularemia as a Biological Weapon. Medical and Public Health Management. JAMA285:27632773.

5. Geissler E (2005) Alibek, Tularaemia and The Battle of Stalingrad. CBW Conv Bull70 $10-15$.

6. Rossow H, Ollgren J, Hytonen J, Rissanen H, Huitu O, et al. (2015) Incidence and seroprevalence of tularaemia in Finland, 1995 to 2013: regional epidemics with cyclic pattern. Euro Surveill20:21209.

7. Splettstoesser WD, Piechotowski I, Buckendahl A, Frangoulidis D, Kaysser P, et al. (2009) Tularemia in Germany: the tip of the iceberg? Epidemiol Infect137:736-743.

8. Akalin H, Helvaci S, GedikoÄŸlu S (2009) Re-emergence of tularemia in Turkey. Int J Infect Dis 13: 547-551.[Crossref]

9. Ariza-Miguel J, Johansson A, Fernández-Natal MI, Martínez-Nistal C, Orduña A, et al. (2014) Molecular investigation of tularemia outbreaks, Spain, 1997-2008. Emerg Infect Dis20: 754-761.

10. Gurycová D, Výrosteková V, Khanakah G, Kocianová E, Stanek G (2001) Importance of surveillance of tularemia natural foci in the known endemic area of Central Europe, 1991-1997. Wien KlinWochenschr113: 433-438.[Crossref]

11. Grunow R, Finke EJ (2002) A procedure for differentiating between the intentiona release of biological warfare agents and natural outbreaks of disease: its use in analyzing the tularemia outbreak in Kosovo in 1999 and 2000. ClinMicrobiol Infect8: 510-521.

12. Bossi P, Tegnell A, Baka A, Van Loock F, Hendriks J, et al. (2004) Bichat clinical guidelines for the clinical management of tularemia and bioterrorism-related tularemia. Euro Surveill12:1-7

13. Short B (2010) War and Disease: War Epidemics in the Nineteenth and Twentieth Centuries. ADF Health11: 15-17.

14. Murray CK, Hinkle MK, Yun HC (2008) History of infections associated with combatrelated injuries. J Trauma 64: S221-231.[Crossref]

15. Ormhaug C (2009) Armed Conflict Deaths Disaggregated by Gender. Oslo: International Peace Research Institute (PRIO), p. 28.

Copyright: (C)2017 Hukić M. This is an open-access article distributed under the terms of the Creative Commons Attribution License, which permits unrestricted use, distribution, and reproduction in any medium, provided the original author and source are credited. 